УДК 004.056.932

doi: $10.26906 /$ SUNZ.2018.1.146

\author{
I.А. Хижняк ${ }^{1}$, О.М. Маковейчук ${ }^{2}$, В.Г. Худов ${ }^{3}$, I.В. Рубан ${ }^{3}$, Г.В. Худов ${ }^{1}$ \\ ${ }^{1}$ Харківський національний університет Повітряних Сил імені Івана Кожедуба, Харків \\ ${ }^{2}$ Національний університет «Львівська політехніка», Львів \\ ${ }^{3}$ Харківський начіональний університет радіоелектроніки, Харків
}

\title{
ТЕМАТИЧНЕ СЕГМЕНТУВАННЯ ЗАШУМЛЕНОГО ОПТИКО-ЕЛЕКТРОННОГО ЗОБРАЖЕННЯ РОЙОВИМ МЕТОДОМ
}

Проведено стислий відомих автоматичних та інтерактивних методів сегментування зображень, їх переваги та недоліки. Встановлено, щзо для сегментування оптико-електронного зображення, щзо отримано з бортової системи спостереження, в умовах впливу иумів доцільно використовувати інтерактивні методи сегментування, взагалі та удосконалений еволюиійний метод сегментування оптико-електронного зображення, щзо заснований на інтегруванні мурашиного та ройового методів, зокрема. Проведено сегментування оптико-електронного зображення в умовах впливу адитивного білого гаусового шуму при різних значеннях середньоквадратичного відхилення та візуальна оцінка якості сегментування. Проведено порівняння удосконаленого еволюиійного методу, щзо заснований на інтегруванні мурашиного та ройового методів 3 відомим методом Канні в умовах впливу адитивного білого гаусового шуму. Встановлено, шяо в умовах впливу адитивного білого гаусового шуму удосконалений еволюиійний метод сегментування, щзо заснований на інтегруванні мурашиного та ройового методів, забезпечує виграш у значенні інформаційного показника відстані Кульбака-Лейбнера від 5\% до 15\%.

Ключові слова: оптико-електронне зображення, тематичне сегментування, ройовий метод, мурашиний метод, еволюиійний метод, бортова система, адитивний білий гаусовий шум, відстань Кульбака-Лейбнера, інформаційний показник, середньоквадратичне відхилення.

\section{Вступ}

Постановка проблеми у загальному вигляді. У теперішній час існує стійка тенденція зростання обсягів даних дистанційного зондування Землі (Д33), що використовуються в інтересах забезпечення діяльності людини в різних сферах: природокористування, господарські потреби, безпека, оборона тощо $[1,2]$.

Зазначене зростання зумовлене підвищенням вимог до інформаційного забезпечення людської діяльності, а також удосконаленням та розвитком техніки (у тому числі засобів Д33), підвищенням інформативності даних Д3З. Значну частку серед таких даних, виходячи з їх наочності та придатності до точних вимірювань, займають дані, що отримані засобами оптико-електронного знімання повітряного та космічного базування.

При розробці бортових систем ДЗЗ виникає цілий клас задач, що пов'язаний з проблемами виявлення, виділення та розпізнавання об'єктів, що знаходяться на оптико-електронних зображеннях [2]. При цьому апріорна інформація щодо характеристик об’єктів інтересу на зображеннях є обмеженою та, у кращому випадку, включає лише приблизні розміри та форму об'єктів інтересу [2]. Між тим бортова апаратура переміщується у просторі разом 3 носієм, крім того ії орієнтацію у просторі можна змінювати за допомогою пристроїв позиціювання [1]. Датчики бортової апаратури випробують впливи різного походження, у зв'язку з чим оптико-електронне зобра- ження, що отримується з бортових систем спостереження, спотворюється. Спотворення ускладнюють, а іноді роблять неможливим здійснення подальшої обробки оптико-електронного зображення з метою його дешифрування. Найбільш впливовими спотвореннями, що впливають на якість оптико-електронного зображення є шум на зображенні, поворот зображення та зміна масштабу зображення [3, 4].

Таким чином, перед розробниками систем обробки зображень стає непроста проблема вибору методів обробки в умовах впливу зазначених вище спотворень.

Це, в свою чергу, зумовлює розробку методів тематичного сегментування зображень в умовах спотворень. В даній роботі основну увагу зосередимо на дослідженні питання тематичного сегментування оптико-електронного зображення в умовах впливу шумів.

Аналіз останніх досягнень і публікацій. Проблема тематичного сегментування оптико-електронного зображення, що отримується з бортової системи спостереження, складна та багатогранна. Зображення має велику інформаційну ємність та апріорну невизначеність, а також велику змінність (зміна ракурсу та освітлення приводить до зміни значень одночасно у всіх елементах зображення) [5, 6]. Крім того, об'єкти, що можуть бути присутніми на зображенні, звичайно входять в складні ієрархічні відношення типу «частина-ціле» та «частина-загальне» [5].

Визначальним моментом у виборі методу розпізнавання об'єктів взагалі та методу тематичного сег- 
ментування зокрема є представлення вихідного зображення. Під представленням зображення розуміється формальна система, що дозволяє отримати у явному вигляді опис об'єктів заданого класу [6]. Основними видами представлень об'єктів при тематичному сегментуванні оптико-електронного зображення $\epsilon$ : низькорівневі [7], ознакові [8, 9], контурні [10], структурні $[5,11]$.

Тематичне сегментування об'єкту на основі опису $Z$ може бути розглянуто як відображення $Z \rightarrow\{Z(j)\}$, де $\{Z(j)\}$ - кінцева множина еталонних описів та реалізується як рішення задачі оптимізації (1) $[12]$ :

$$
\mathrm{j}^{*}=\arg \max _{\mathrm{j} \in \mathrm{J}} \vartheta(\mathrm{Z}, \mathrm{Z}(\mathrm{j})), \mathrm{j}^{*} \in \mathrm{J},
$$

де J - множина класів; $\vartheta(Z, Z(j))$ - міра подібності Z та $Z(j)$.

При визначенні міри подібності $\vartheta(Z, Z(j))$ розраховується потужність $\mu\left(Z_{j}\right)$ підмножини $Z_{j} \subseteq Z$, для елементів якого встановлена еквівалентність $Z(j)$, та при рішенні (1) визначається $Z_{j}$ найбільшої потужності. Якщо $\mu(\bullet)$ - потужність множини, то значення виразів $\mu\left(Z_{j^{*}}\right) / \mu(Z)$ або $\mu\left(Z_{j}^{*}\right) / \mu(Z(j))$ трактуються як оцінка апостеріорної імовірності віднесення $Z$ до класу j. Розрахунок $\mu\left(Z_{j}\right)$ для моделі $Z$ зводиться до побудови на множині $Z$ представлення $Z=\bigcup Z_{j}$ у вигляді розбивки $\left(Z_{i} \bigcap_{\mathrm{i} \neq \mathrm{j}} Z_{j}\right)=\varnothing$ або покриття $\left(\mathrm{Z}_{\mathrm{i}} \bigcap_{\mathrm{i} \neq \mathrm{j}} \mathrm{Z}_{\mathrm{j}}\right) \neq \varnothing$ їх елементів, які отримують мітку класу ј при відображенні $\mathrm{Z} \rightarrow \mathrm{J}[5,12]$.

Складність тематичного сегментування оптикоелектронного зображення, що отримано з бортових систем спостереження, також обумовлена [13]:

- по-перше, аномаліями (невеликими областями зображення), які можуть бути прийнятими за шум або дефект зображення;

- по-друге, невідомою формою та нечіткими границями об'єктів інтересу.

У теперішній час існує достатня кількість методів сегментування, які мають переваги та недоліки. Але не існує одного універсального методу, тому для кожної задачі тематичного сегментування в загальному випадку необхідно підбирати вручну метод, який спроможний видавати найкращий результат.

Широкий спектр методів сегментування зображень описаний в різній літературі, наприклад, досить повний огляд таких методів наведено в [13-15]. Методи сегментування поділяються на два класи: автоматичні [14] - не потребують взаємодії з користувачем; інтерактивні [15] - в процесі роботи потребується участь користувача.
Існує два класи задач автоматичного сегментування [14, 15]:

- визначення областей зображення 3 певними властивостями;

- дроблення зображення на однорідні області.

Найбільш популярними та відомими методами автоматичного сегментування є: метод k-середніх, гістограмні методи, оператори виділення границь, методи розростання областей, методи розрізу графа та інші [15]. Так, наприклад, метод k-середніх заснований на мінімізації квадратичної помилки. Метод проводить кластеризацію точок (пікселів) на зображенні (побудову k кластерів [15]). Вибір числа кластерів k, як правило, базується на результатах попередніх досліджень або на основі експертної оцінки. Але в процесі сегментування зображення метод k-середніх не виключає зайву інформацію, таку, наприклад, як шуми різного походження.

Метод сегментування 3 використанням нейронної мережі Кохонена [16] представляє двохшарову мережу - кожен нейрон першого (розподільчого) шару поєднаний з усіма нейронами другого (вихідного) шару, які розташовані у вигляді двомірної решітки. Основний істотний недолік автоматичних методів сегментування - недостатня точність роботи [15]. 3 аналізу результатів, наведених в $[13,14]$, зрозуміло, що нові методи автоматичного сегментування не зможуть вирішити абсолютно всі завдання сегментування 3 необхідним результатом. I, більш того, є підстави вважати, що у найближчий час такі методи не з'являться [17].

У зв'язку з цим, більша увага приділяється інтерактивним методам сегментування [15]. В основі розроблених методів лежать ройові методи, до яких відносяться [18]: метод рою частинок, мурашиний метод, бджолиний метод, штучна імунна система, метод капель води, метод зозулі, метод альтруїзму, метод гравітаційного пошуку. Ройові методи показали свою спроможність щодо сегментування оптико-електронних зображень при рішенні NP-повних комбінаторних задач у порівнянні з генетичними методами [16]. В [16] також розроблено метод сегментування оптико-електронного методичного зображення 3 використанням змішаного методу kсередніх, рою частинок та експоненціального методу рою частинок. Використання методів, що отримано в [16] до сегментування оптико-електронного зображення, що отримано з бортової системи оптико-електронного спостереження, не можливо, так як потребує зміни цільова функція (фітнес-функція), не враховано особливості формування зображення, особливості функціонування бортових систем спостереження та інше.

Сегментування оптико-електронного зображення, що отримано з бортової системи спостереження мурашиним методом розглянуто в роботі [19]. В [19] викладена сутність простішого еволю- 
ційного методу сегментування оптико-електронного зображення, який відноситься до мурашиних методів, проведено удосконалення простішого еволюційного методу сегментування зображення, проведена перевірка працездатності простішого та удосконаленого еволюційних методів сегментування на контрольному прикладі, проведені експериментальні дослідження щодо сегментування еволюційним методом зображення, що отримано з бортової системи оптико-електронного спостереження.

В [20] викладена сутність простішого ройового методу сегментування оптико-електронного зображення, що отримано з бортової системи спостереження, проведено експериментальні дослідження щодо застосування ройового методу до сегментування зображення, що отримано з бортової системи оптико-електронного спостереження, проведена візуальна оцінка якості сегментованого зображення та виділені можливі об'єкти інтересу для подальшого дешифрування оптико-електронного зображення.

В [21] для підсилення переваг та послаблення недоліків еволюційного (мурашиного) методу та ройового методів запропоновано ройовий інтелект на основі інтеграції моделей адаптивної поведінки мурашиної та бджолиної колоній. Але напряму результати роботи [21] не можуть бути використані при сегментуванні оптико-електронного зображення, що отримано 3 бортової системи оптикоелектронного спостереження.

В [22] наведено удосконалений еволюційний метод сегментування оптико-електронного зображення, що заснований на інтегруванні мурашиного та ройового методів.

Однак, відомі методи сегментування зображень, що отримані 3 бортових систем оптикоелектронного спостереження, не досліджувалися на стійкість до різного роду спотворень.

Мета статті - провести оцінку ефективності тематичного сегментування оптико-електронного зображення, що отримано з бортової системи спостереження, в умовах впливу шумів ройовим методом

\section{Постановка задачі та викладення матеріалів дослідження}

У якості ройового методу сегментування будемо використовувати удосконалений еволюційний метод сегментування оптико-електронного зображення, що заснований на інтегруванні мурашиного та ройового методів [22]. Сутність мурашиного еволюційного методу викладена в роботі [19], а сутність ройового методу викладена в роботі [20]. Удосконалений еволюційний метод сегментування оптико-електронного зображення, що заснований на інтегруванні мурашиного та ройового методів, наведений на рис. 1.

У виразі (2) позначені такі складові: $\mathrm{P}_{\mathrm{i}}^{\mathrm{m}}(\mathrm{t})$ - імовірність переходу т-го агента (мурахи) в і-у ПТМ з вра- хуванням привабливості і-ї ділянки маршруту Li та концентрації феромонів на цій ділянці Fi в момент часу $\mathrm{t} ; \mathrm{J}$ - кількість можливих ПТМ; $\alpha$ і $\beta$ - параметри, що задають вагу феромона і привабливості ділянки («жадібність» методу), відповідно.

Вибір вихідної точки (ВТМ) та сукупності поворотних точок (ПТМ) маршруту

Початкове відкладення феромону на маршрутах ВТМ-кожна з обраних ПТМ

Обчислення цільової (фітнес) функції $\mathrm{f}\left(\mathrm{x}_{\mathrm{i}}, \mathrm{Z}\right)$ для кожної ПТМ

Вирішення двох оптимізаційних задач:

- зведення до мінімуму внутрішніх відстаней між пікселями кластерів та їх середніми;

- зведення до максимуму зовнішніх відстаней між любими парами кластерів

Формування рівня феромону на маршрутах між обраними ПТМ

Побудова множини маршрутів між ПТМ відповідно до ймовірнісного правила (2):

$$
\mathrm{P}_{\mathrm{i}}^{\mathrm{m}}(\mathrm{t})=\mathrm{F}_{\mathrm{i}}(\mathrm{t})^{\alpha} \cdot \mathrm{L}_{\mathrm{i}}{ }^{\beta} / \sum_{\mathrm{j}=1}^{\mathrm{J}} \mathrm{F}_{\mathrm{j}}(\mathrm{t})^{\alpha} \cdot \mathrm{L}_{\mathrm{j}}{ }^{\beta}
$$

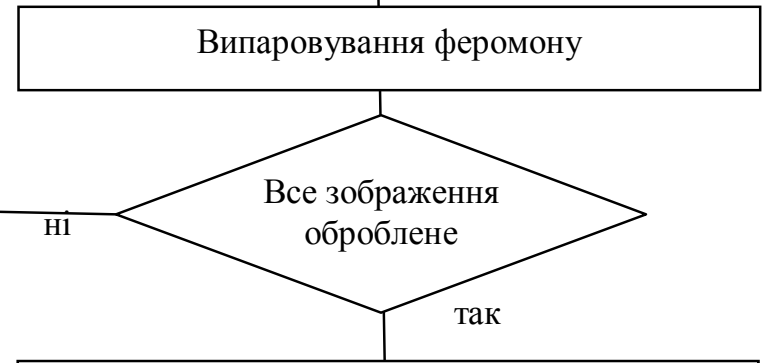

Формування сегментованого зображення

Рис. 1. Удосконалений еволюційний метод сегментування оптико-електронного зображення, що заснований на інтегруванні мурашиного та ройового методів [22]

У якості вихідного будемо розглядати зображення, що отримано з бортової системи оптико-електронного спостереження (рис. 2 [23]).

В роботі будемо використовувати модель спотворення, що представлена адитивним білим гаусовим шумом (АБГШ). Реалізацією АБГШ є двомірний випадковий процес з нульовим середнім, заданою дисперсією та гаусовою щільністю розподілу. При моделюванні реалізація шуму додавалася до вихідного незашумленого зображення (рис. 2). 


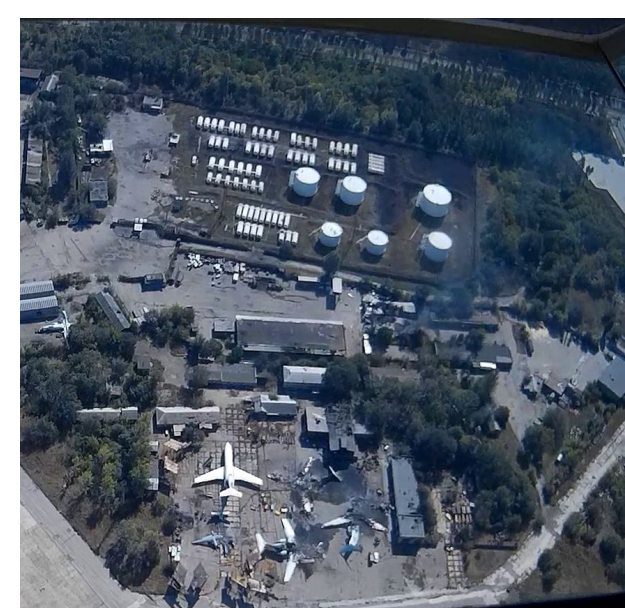

Рис. 2. Вихідне зображення [23]

Модель перешкоди та зображення може бути представлена виразом

$$
\mathrm{I}_{\mathrm{mI}}^{\text {aдд }}(\mathrm{i}, \mathrm{j})=\mathrm{I}_{0}(\mathrm{i}, \mathrm{j})+\mathrm{N}_{\text {гаус }}(\sigma),
$$

де $(\mathrm{i}, \mathrm{j})$ - координати пікселів на зображенні; $\mathrm{I}_{0}(\mathrm{i}, \mathrm{j})$ вихідне зображення без перешкод; I⿰氵工丁口 ження, що спотворене АБГШ; $\mathrm{N}_{\text {гаус }}(\sigma)$ - АБГШ 3 нульовим середнім та заданим середньоквадратичним відхиленням $\sigma$.

На рис. 3 - 5 наведені зображення $\mathrm{I}_{\amalg}^{\mathrm{a} д д ~}(\mathrm{i}, \mathrm{j})$ що спотворене АБГШ з нульовим середнім та заданими середньоквадратичними відхиленнями $\sigma=0,05$, $\sigma=0,25$ та $\sigma=0,5$ відповідно.

Результати сегментування зображень, що наведені на рис. 2 - 5 удосконаленим еволюційний методом, що заснований на інтегруванні мурашиного та ройового методів [22], наведені на рис. 6 - 9 відповідно. При цьому наведені результати сегментування полутонового (у відтінках сірого) зображень.

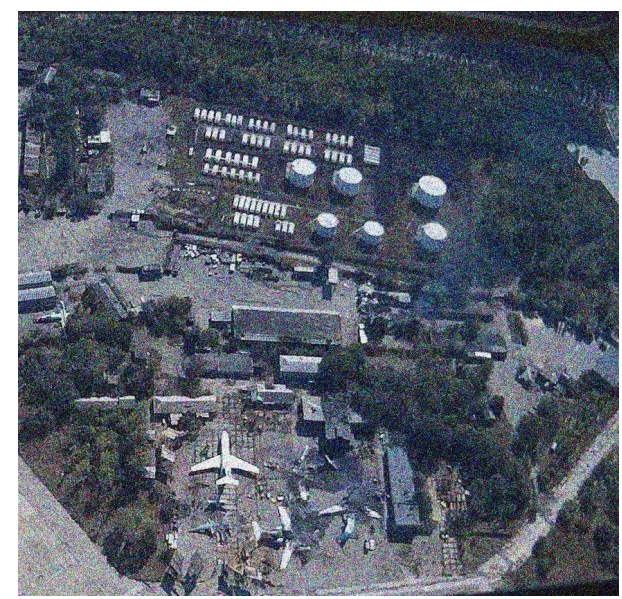

Рис. 3. Зображення $I_{\amalg}^{\text {адд }}(\mathrm{i}, \mathrm{j})$, що спотворене

АБГШ з нульовим середнім та заданим середньоквадратичним відхиленням $\sigma=0,05$

3 аналізу результатів сегментування, що наведені на рис. 6-9, видно, що наявність АБГШ суттєво впливає на якість сегментування оптико-електронного зображення: з'являються артефакти обробки на краях зображення, контури об'єктів стають нечіткими, спостерігається ефекти, які притаманні змазуванню та розфокусуванню зображення.

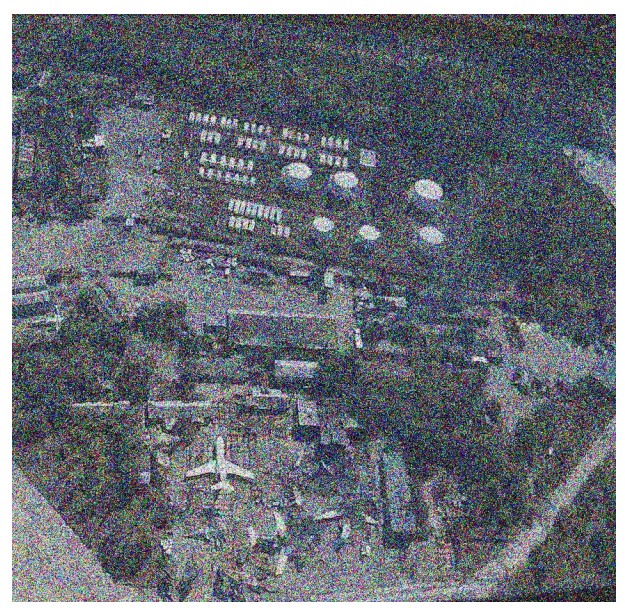

Рис. 4. Зображення I⿰氵 $I_{\amalg}^{\text {адд }}(i, j)$, що спотворене

АБГШ з нульовим середнім та заданим середньоквадратичним відхиленням $\sigma=0,25$

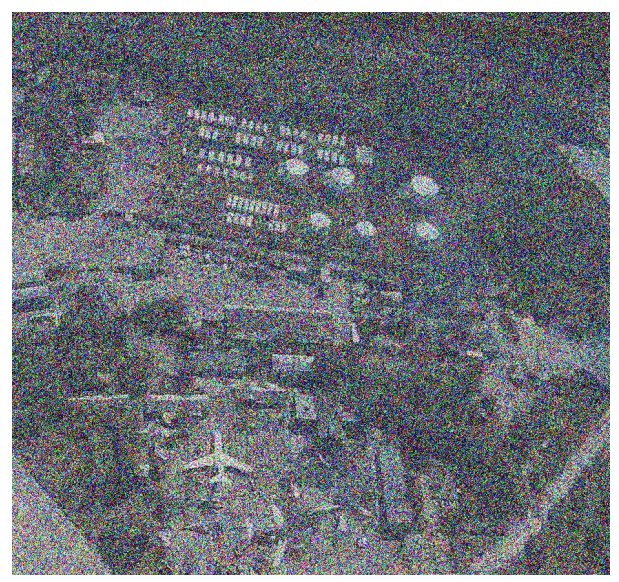

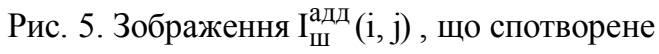

АБГШ з нульовим середнім та заданим середньоквадратичним відхиленням $\sigma=0,5$

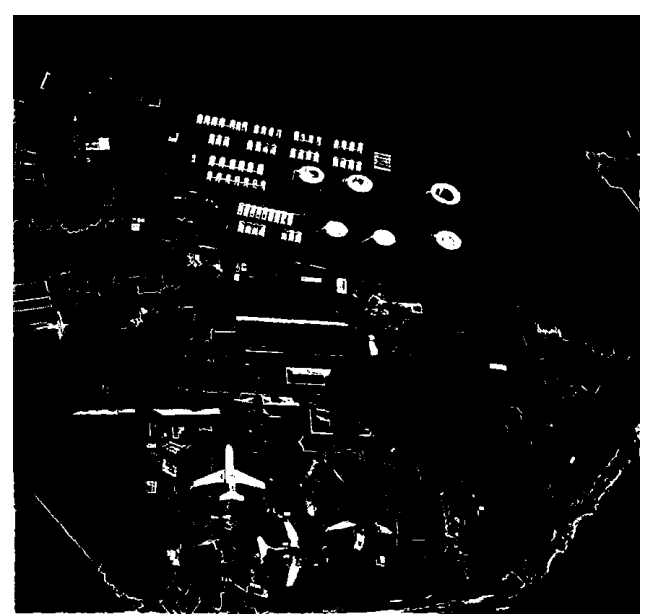

Рис. 6. Результат сегментування вихідного зображення (рис. 2) 


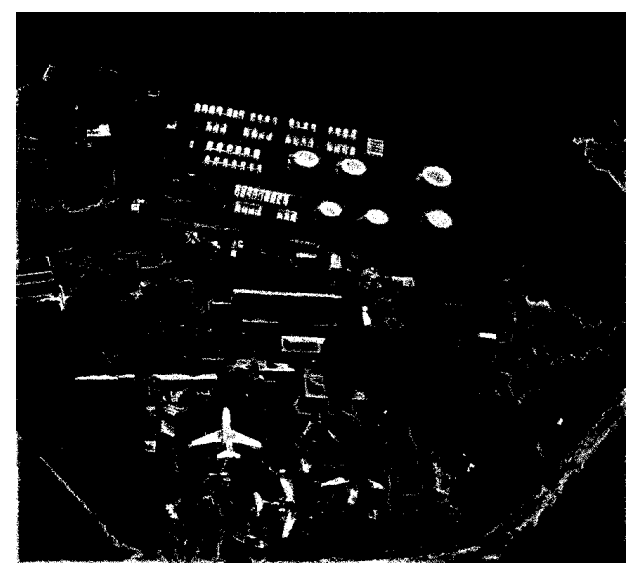

Рис. 7. Результат сегментування зображення $\mathrm{I}_{\amalg}^{\text {адд }}(\mathrm{i}, \mathrm{j})$, що спотворене АБГШ з нульовим середнім та заданим середньоквадратичним відхиленням $\sigma=0,05$ (рис. 3)

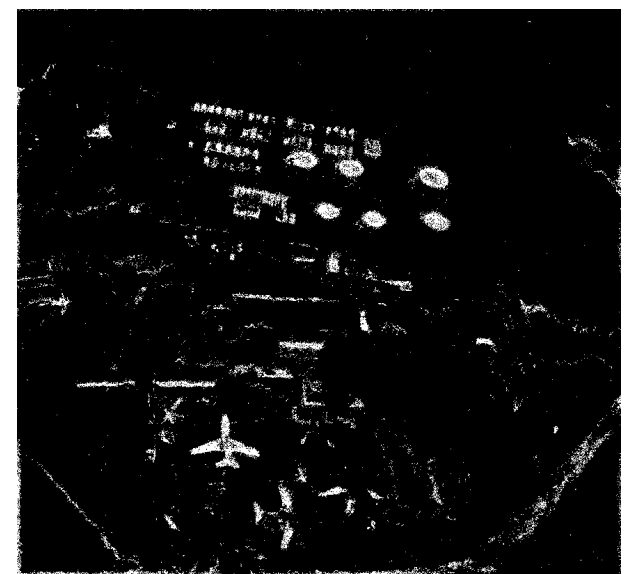

Рис. 8. Результат сегментування зображення $\mathrm{I}_{\amalg}^{\text {адд }}(\mathrm{i}, \mathrm{j})$, що спотворене АБГШ з нульовим середнім та заданим середньоквадратичним відхиленням $\sigma=0,25$ (рис. 4)

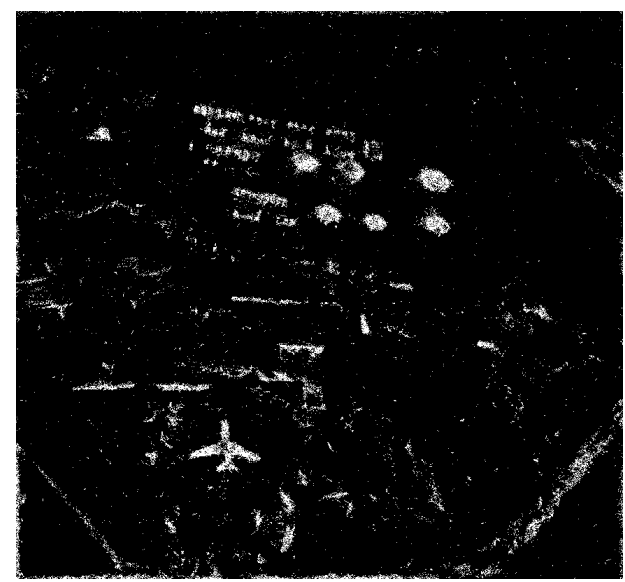

Рис. 9. Результат сегментування зображення $\mathrm{I}_{\amalg}^{\text {адд }}(\mathrm{i}, \mathrm{j})$, що спотворене АБГШ з нульовим середнім та заданим середньоквадратичним відхиленням $\sigma=0,5$ (рис. 5)

Проведемо кількісну оцінку ефективності сегментування зображення, що отримано з бортової системи оптико-електронного спостереження та спотворене АБГШ з нульовим середнім та заданим середньоквадратичним відхиленням. У якості показника ефективно- сті будемо використовувати інформаційний показник відстань Кульбака-Лейбнера $\mathrm{K}\left(\mathrm{p}_{\xi}, \mathrm{p}_{\eta}\right)$ [24], яка може бути розрахована за виразом (4):

$$
\mathrm{K}\left(\mathrm{p}_{\xi}, \mathrm{p}_{\eta}\right)=\int_{\mathrm{R}^{2}} \mathrm{p}_{\xi}(\mathrm{x}) \log \frac{\mathrm{p}_{\xi}(\mathrm{x})}{\mathrm{p}_{\eta}(\mathrm{x})} \mathrm{dx},
$$

де $\mathrm{p}_{\xi}$ - розподіл яскравості на вихідному зображенні; $\mathrm{p}_{\eta}$ - розподіл яскравості на сегментованому зображенні; $\mathrm{R}^{2}$ - площина зображення.

Для більшої наочності проведемо порівняння удосконаленого еволюційного методу, що заснований на інтегруванні мурашиного та ройового методів [22], 3 відомими методами сегментування. У якості відомого методу сегментування обрано метод Канні, властивості якого досліджувалися авторами в роботі [25]. Для прикладу на рис. 10, 11 наведені результати сегментування зображень, що наведені на рис. 4, 5, методом Канні. Наведені результати сегментування полутонового (у відтінках сірого) зображень.

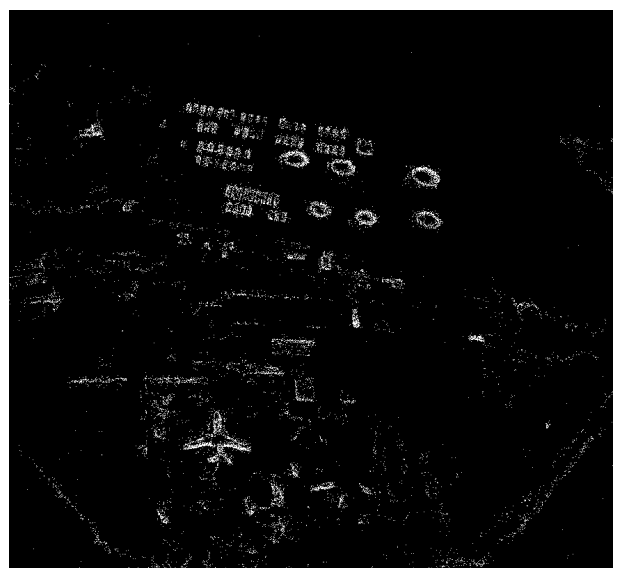

Рис. 10. Результат сегментування методом Канні зображення $\mathrm{I}_{\amalg}^{\text {адд }}(\mathrm{i}, \mathrm{j})$, що спотворене АБГШ 3 нульовим середнім та заданим середньоквадратичним відхиленням $\sigma=0,25$ (рис. 4)

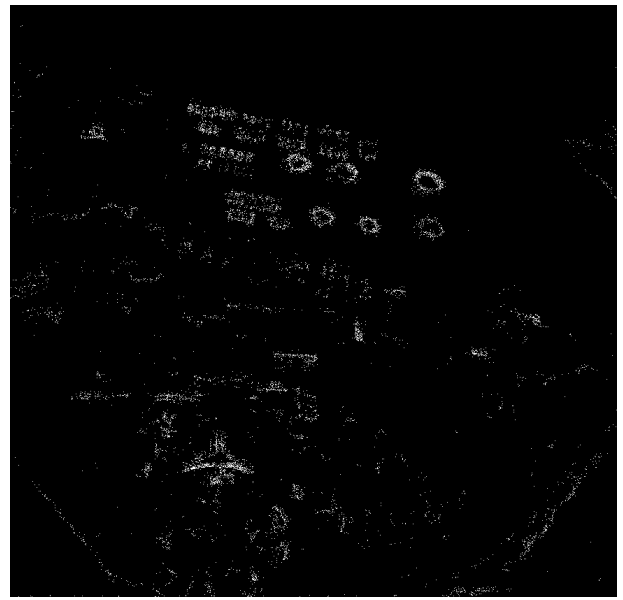

Рис. 11. Результат сегментування методом

Канні зображення $\mathrm{I}_{\amalg}^{\text {адд }}(\mathrm{i}, \mathrm{j})$, що спотворене

АБГШ з нульовим середнім та заданим середньоквадратичним відхиленням $\sigma=0,5$ (рис. 5) 
3 порівняння рис. 8 та 10, рис. 9 та 11 візуально видно, що якість рис. 8 та 9 краще за якість рис. 10 та 11. Це свідчить про кращу ефективність удосконаленого еволюційного методу сегментування, що заснований на інтегруванні мурашиного та ройового методів [22], у порівнянні з відомим методом сегментування Канні [25]. На рис. 12 наведений графік залежності відстані Кульбака-Лейбнера $\mathrm{K}\left(\mathrm{p}_{\xi}, \mathrm{p}_{\eta}\right)$ від зміни значення середньоквадратичного відхилення $\sigma$ при сегментуванні оптико-електронного зображення 3 використанням удосконаленого еволюційного методу сегментування, що заснований на інтегруванні мурашиного та ройового методів [22], та відомого методу сегментування Канні [25]. Для кожного значення середньоквадратичного відхилення АБГШ в діапазоні від 0 до 0,5 з кроком 0,05 розраховувалась відстань КульбакаЛейблера між еталонним і обробленим зображенням для різних методів сегментування. Відстань КульбакаЛейбнера розраховувалась за виразом (4) 3 використанням логарифму за основою 2, отже відстань Кульбака-Лейбнера вимірюється у бітах, а для зображення в градаціях сірого (полутонового зображення) $(0 . .2555)$ максимальне значення відстані КульбакаЛейбнера дорівнює 8. 3 аналізу рис. 12 видно, що удосконалений еволюційний метод сегментування, що заснований на інтегруванні мурашиного та ройового методів [22], забезпечує значний виграш у порівнянні 3 відомим методом сегментування Канні [25].

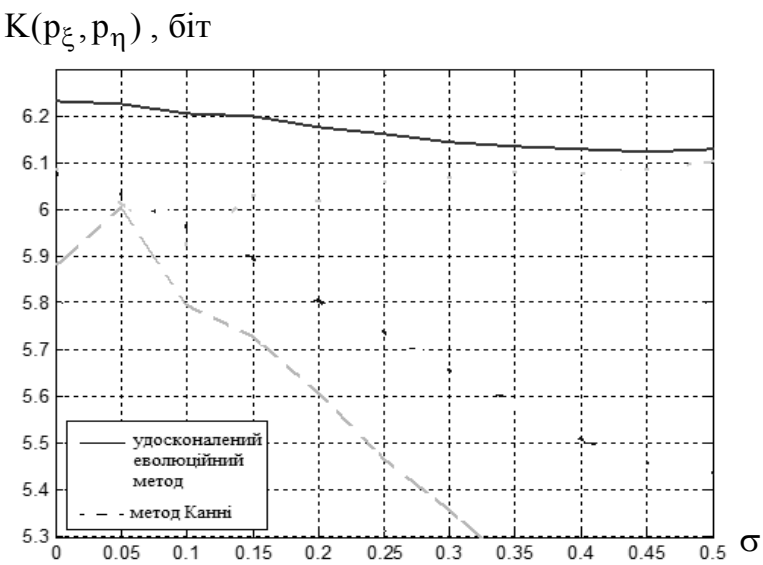

Рис. 12. Залежність відстані Кульбака-Лейбнера від заданого значення середньоквадратичного відхилення при різних методах сегментування

\section{Висновки і напрямки подальших досліджень}

Таким чином, в роботі:

- встановлено, що оптико-електронне зображення, що отримується з бортових систем спостереження, спотворюється, що ускладнюе подальшу обробку оптико-електронного зображення 3 метою його дешифрування;

- проаналізовано відомі методи сегментування зображень, які поділяються на два класи: автоматичні та інтерактивні, їх переваги та недоліки;
- встановлено, що для сегментування оптикоелектронного зображення, що отримано з бортової системи спостереження, в умовах впливу шумів доцільно використовувати удосконалений еволюційний метод сегментування оптико-електронного зображення, заснований на інтегруванні мурашиного та ройового методів, зокрема;

- проведено сегментування оптико-електронного зображення в умовах впливу АБГШ при різних значеннях середньоквадратичного відхилення та візуальна оцінка якості сегментування;

- у якості показника оцінки якості сегментування обрано інформаційний показник - відстань Кульбака-Лейбнера;

- проведено порівняння удосконаленого еволюційного методу, що заснований на інтегруванні мурашиного та ройового методів з відомим методом Канні в умовах впливу АБГШ;

- встановлено, що в умовах впливу АБШГ удосконалений еволюційний метод сегментування, що заснований на інтегруванні мурашиного та ройового методів, дає виграш у значенні інформаційного показника - відстані Кульбака-Лейбнера від 5 до 15\%.

Напрямками подальщих досліджень є:

- порівняння результатів сегментування оптико-електронного зображення, що отримано з бортової системи оптико-електронного спостереження, при впливі шумів з іншими відомими методами сегментування;

- дослідження якості тематичного сегментування оптико-електронного зображення, що отримано $з$ бортової системи оптико-електронного спостереження, при впливі шумів, відмінних від АБШГ.

\section{Список літератури}

1. Шовенгердт Р.А. Дистанциионное зондирование. Модели и методы обработки изображений / Р.А. Шовенгердт. - М.: Техносфера, 2010. -560 c.

2. Попов М.О. Стан і перспективи розвитку гіперспектральних систем аерокосмічної розвідки / М.О. Попов, С.В. Гринюк // Наука і оборона. - К., 2012. - № 2. - С. 39-47.

3. Меньшаков Ю.К. Техническая разведка из космоса / Ю.К. Меньшаков. - М. : Academia, 2013. - 656 c.

4. Ким Н.В. Алгоритм управления группой беспилотных летательных аппаратов / Н. В. Ким, И. Г. Крылов // Робототехника и техническая кибернетика, 2014. -№ 4. - C. 40-43.

5. Hörster E. Image retrieval on large-scale image databases / E.Hörster, R.Lienhart, M.Slaney // Proc. 6th ACM int. conf. on Image and Video Retrieval, CIVR 2007, 2007. - P. 17-24.

6. Потапов А.С. Исследование представлений изображений на основе приниипа репрезентачионной длины описания / Потапов А.С. // Изв. вузов., 2008. - Т. 51. - № 7. - С. 3-7.

7. Марр Д. Зрение. Информачионный подход к изучению представления и обработки зрительных образов / Д. Марр. М.: Радио и связь, 1987. - 400 c.

8. Chan T.F. Variational PDE models in image processing / T.F.Chan, J.Shen, L.Vese // Notice AMS, 2003. - V. 50. - P. 14-26.

9. Lei B.J. On feature extraction from images. Technical Report, Deliverable 2.1.1.2.A+B, MCCWS project, Information and Communication Theory Group / B.J.Lei, E.A.Hendriks, M.J.T.Reinders. - TU Delft, 1999. - 57 p. 
10. Baker S. Design and Evaluation of Feature Detectors: PhD thesis / S.Baker. - Columbia University, 1998. - 167 p.

11. Фурман Я.А. Введение в контурный анализ и его приложения к обработке изображений и сигналов / Я.А. Фурман. - М.: Физматлит, 2002. - 592 c.

12. Гороховатский В.А. Системы признаков на основе отномений структурных элементов изображений / В.А. Гороховатский // Бионика интеллекта, 2011. - № 1 (75). - C. 48-51.

13. Choudhary R. Recent trends and techniques in image enhancement using differential evolution - a survey. R. Choudhary, $R$. Gupta // Int. journal of adv. research in computer science and software engineering, 2017. - Vol. 7. - № 4. - P. 106-112.

14. Конушин В.В. Методы сегментачии изображений: автоматическая сегментация / В.В. Конушин, В.А. Вежневеи // Вестник МГУ, 2009. - №5. - C. 50-55.

15. Конушин В.В. Методы сегментаџии изображений: интерактивная сегментаиия / В.В.Конушин, В.А.Вежневеи // Вестник МГУ, 2008. - №4. - С. 107-118.

16. Dong $G$. Color clustering and learning for image segmentation based on neural networks / G. Dong, M. Xie // Neural Networks, IEEE Trans., 2005. - Vol. 16. 4. - P. 925-936.

17. Эль-Хатиб С.А. Сегментачия изображений $c$ помощью смешанного и экспоненичильного роя частиц / С.А.Эль-Хатиб // Информатика и кибернетика, 2015. - № 1. - C. $126-133$.

18. Водолазский И.А. Роевой интеллект и его наиболее распространенные методы реализачии / И.А.Водолазский, А.С.Егоров, А.В.Краснов // Молодой ученый, 2017. - № 4 (138). - C. 147-153.

19. Ruban I. Segmentation of the images obtained from onboard optoelectronic surveillance systems by the evolutionary method / I. Ruban, H. Khudov, V. Khudov, I. Khizhnyak, O. Makoveichuk // Eastern-European Journal of Enterprise Technologies, 2017. - № 5/9 (89). - P. 49-57.
20. Хижняк I.А. Сегментування зображення, що отримано з бортової системи оптико-електронного спостереження, ройовим методом / I.А. Хижняк // Системи озброєння та військова техніка. Науковий журнал, 2017. - № 2 (50). - C. 140-143.

21. Лебедев В.Б. Роевой интеллект на основе интеграчии моделей адаптивного поведения муравьиной и пчелиной колоний / В.Б. Лебедев, О.Б. Лебедев // Известия ЮФУ. Технические науки, 2013. - № 7. - C. 41-47.

22. Хижняк I.A. Інтегрування мурашиного та ройового методів сегментування зображення, що отримано 3 бортової системи оптико-електронного спостереження / I.А. Хижняк // Системи управління, навігащії та зв'язку, 2017. - Bun. 6 (46). - C. 61-64.

23. IKONOS Satellite Images Gallery, Satellite Map [Electronic resource] / Satellite Imaging Corporation. Access mode: URL: http://www.satimagingcorp.com/gallery/ ikonos - 20.01.2017 year.

24. Худов В.Г. Очінка якості сегментування оптикоелектронного зображення шияхом оцінки комплексних показників та відстані Кульбака-Лейбнера / В.Г. Худов, О.М. Маковейчук, І.А. Хижняк // Системи обробки інформачїі, 2017. - Bun. 4 (150). - C. 27-30.

25. Очінка відстані Кульбака-Лейбнера при тематичному сегментуванні оптико-електронного зображення методом Канні / Г.В. Худов, В.Г. Худов, І.А. Хижняк, I.В. Новікова // Сучасні інформачійні технологї̈ у сфері безпеки та оборони, 2017. - № 2 (29). - C. 83-90.

Надійшла до редколегії 15.01.2018

Рецензент: д-р техн. наук, проф. О.О. Морозов, Національна академія Національної гвардії України, Харків.

\section{ТЕМАТИЧЕСКАЯ СЕГМЕНТАЦИЯ ЗАШУМЛЕННОГО ОПТИКО-ЭЛЕКТРОННОГО ИЗОБРАЖЕНИЯ РОЕВЫМ МЕТОДОМ}

\section{И.А. Хижняк, А.Н. Маковейчук, В.Г. Худов, И.В. Рубан, Г.В. Худов}

Проведено короткий анализ известных автоматических и интерактивных методов сегментации изображений, их достоинства и недостатки. Установлено, что для сеглентации оптико-электронного изображения, полученного с бортовой системь оптико-электронного наблюдения, в условиях воздействия шумов целесообразно использовать интерактивные методы сегментации вообще и усовершенствованный эволюиионный метод сегментации оптико-электронного изображения, который основанный на интегрировании муравьиного и роевого методов, в частности. Проведена сегментация оптико-электронного изображения в условиях воздействия аддитивного белого гауссова шума при разных значениях среднеквадратического отклонения и визуальная оценка качества сегментации. Проведена сравнительная оценка усовериенствованного эволюционного метода, который основан на интегрировании муравьиного и роевого методов с известным методом Канни. Установлено, что в условиях воздействия аддитивного белого гауссова шума усовершенствованный эволючионный метод сегментаиии, который основан на интегрировании муравьиного и роевого методов, обеспечивает выигрыш в значении информационного показателя - расстоянии Кульбака-Лейбнера от 5\% до $15 \%$.

Ключевые слова: оптико-электронное изображение, тематическая сегментачия, роевой метод, муравьиный метод, эволюиионный метод, бортовая система, аддитивный бельй гауссовый шум, расстояние Кульбака-Лейбнера, информационный показатель, среднеквадратическое отклонение.

\section{THEMATIC SEGMENTATION OF THE SLIPED OPTICAL-ELECTRONIC IMAGE WITH A SWARM METHOD}

I.A. Khizhnyak, A.N. Makoveychuk, V.G. Khudov, I.V. Ruban, H.V. Khudov

A short analysis of known automatic and interactive methods of image segmentation, their advantages and disadvantages is carried out. It has been found that for segmentation of the optic-electronic image obtained from the on-board optic-electronic observation system, it is advisable to use interactive segmentation methods in general and an improved evolutionary method for segmentation of the optoelectronic image, which is based on the integration of the ant and swarm methods, in particular. Segmentation of the opticelectronic image under the influence of additive white Gaussian noise at different values of the root-mean-square deviation and a visual assessment of segmentation quality were carried out. A comparative evaluation of the improved evolutionary method is carried out, which is based on integrating the ant and swarm methods with the known Canni method. It is established that under the influence of additive white Gaussian noise, the improved evolutionary segmentation method, which is based on the integration of the ant and swarm methods, provides a gain in the value of the information indicator - Kulbak-Leibner distance from $5 \%$ to $15 \%$.

Keywords: optic-electronic image, thematic segmentation, swarm method, ant method, evolution method, airborne system, additive white Gaussian noise, Kullback-Leibner distance, information indicator, standard deviation. 